\title{
The Effect of Bangunbangun (Plectranthus amboinicus $L$. Spreng) Supplemented in Feed on the Quality of Broiler Chicken Meat
}

\author{
Melva Silitonga ${ }^{1}$, and Nindi Syaputri ${ }^{2}$ \\ \{melvasilitonga2013@gmail.com ${ }^{1}$, nindisyahputri55@gmail.com ${ }^{2}$ \} \\ Biology Department Universitas Negeri Medan ,Medan Indonesia ${ }^{1,2}$ \\ Jl. Willem Iskandar Psr. V, Medan Estate, Medan, Indonesia, 20221
}

\begin{abstract}
This study aims to determine the effect of feed supplemented with Bangunbangun (Plectranthus amboinicus) leaf flour (PF) on the quality of broiler chicken meat. Meat quality is determined based on observations of parameters of body weight, percentage of carcass, liver weight, and meat cholesterol. This type of research is an experimental study with a completely randomized design (CRD), consisting of five treatments and five replications. The treatments were P0 as control, P1, P2, P3, and P4 respectively given commercial feed treatment $+0 \% \mathrm{PF}$, commercial feed $+10 \% \mathrm{PF}$, commercial feed $+15 \% \mathrm{PF}$ and commercial feed $+20 \%$ PF. from two chickens so the total number of chickens used by 50 chickens. Feed and drinking water are given ad libitum. Treatment was given for 35 days. On the 36th day all chickens were cut, for observation of body weight, percentage of carcass, liver weight, and meat cholesterol. The data obtained were tabulated and analyzed using one-way ANOVA and continued with LSD test using SPSS 21.0. The results showed that the higher giving of wake-up leaf flour reduced the weight of the liver and cholesterol levels of meat. Supplementation of $20 \%$ PF flour in feed does not affect broiler chicken body weight.
\end{abstract}

Keywords: Plectranthus amboinicus , carcass, liver weight, meat cholesterol

\section{Introduction}

Broiler is one of the most popular sources of animal protein in the community, in addition to its affordable price; this chicken meat tastes good and easily obtained. The problem that often arises is the high level of cholesterol in chicken meat so that many people avoid it, especially parents or people who are already inclined to have high cholesterol levels in their blood.

To overcome the high cholesterol in chicken meat, it can be done through modification of the commercial feed which can reduce cholesterol levels. This modification can be done by supplementing vegetables in the feed. In this study Bangunbangun (Plectranthus amboinicus L. Spreng) was chosen. Bangunbangun (Plectranthus amboinicus L. Spreng) was chosen as an ingredient in chicken feed supplementation which contained several components, such us various vitamins and secondary metabolites which were very useful. This Statement also proven by Koti et al (2011) research about the activity of Bangunbangun (Plectranthus amboinicus L. Spreng) as antihyperglycemic and antihyperlipidemic on normal and alloxaninduced diabetic rats. 
The composition of broiler meat explained by Kumar (2017). There are three different brand of broiler meat with different protein content. The highest protein was found in broiler meat from the second brand, with 18, $06 \pm 0,13(\mathrm{P}>0,05) .23 \%$ protein was given into broiler commercial feed also affect the body weight and protein percentage in the meat. Meanwhile the highest fat percentage found in broiler from the first brand with 22, $30 \pm 0,91$ in broiler drumstick meat, and 0,02 $\pm 0,000$ in broiler breast meat. This research also explained that protein profile, amino acid, and fat acid also affect the cholesterol balance in broiler meat.

Drumstick is the part that taken to be a sample to analyzed the meat cholesterol. This part is the most favorite part to consumed by people because its taste. But, this part has the highest cholesterol levels compared to another part of chicken body (Marangoni et al (2015).

As a potential vegetable that can help to reduce the cholesterol level in broiler meat trough feed supplementation, Bangunbangun (Plectranthus amboinicus L. Spreng) contain several component such as various vitamin and secondary methabolites. Niacin is one of the compounds that found in bangunbangun which is a derivate of vitamin B3 which function in regulating blood glucose. According to Marangoni et al (2015), niacinis proven to increase levels of free fatty acid, so that the ability of pancreatic beta cells to produce insulin is important to prevent an increase in blood glucose. Niacin can reduce the cholesterol and quail blood serum fat at dose of $600 \mathrm{ppm}(\mathrm{sig}<0,05)$. According to Asimwee (2014) research about the chemical compounds and the toxicological evaluation of bangunbangun leaves showed that it was contained some bioactive compound,like saponin, tannin, flavonoides, and steroids glycosides.

\section{Material And Method}

\subsection{Plant Material and Flour Preparation}

Bangunbangun leaves were harvested from Animal House yard that have been planted since September 2017. The best leaves to use are the shoot leaves to the third leaves from the base of the stem. A month old bangunbangun leaves are picked and washed, then drained and aerated for a night. After aerated, the leaves are finely sliced and dried using an oven at $40{ }^{\circ} \mathrm{C}$ to dry and brittle. Dried leaves are blended until smooth and sifted using calico fabric

\subsection{Chicken Food and Bangunbangun Flour Supplementation}

The Starter and Finisher commercial feed that used in this research was obtained from PT. Charoen Pokphand Indonesia. Provision of feed with supplementation of bangunbangun leaf flour was as follows.

Commercial feed is mashed, then mixed homogeneously with bangunbangun flour. For starter chicken the feed is left smooth. While to feed finisher chicken after commercial feed is mashed and mixed with bangunbangun leaf flour, given a little water then formed according to the size of the pellet. Supplementation of leaf flour wake up in accordance with a ratio of 5 , 10,15 and 20 percent 


\subsection{Broiler Chicken's Cage}

The chicken cages that used are 25 plots of cages with a multilevel battery system. The size of each cage is $60 \mathrm{~cm}$ length, $50 \mathrm{~cm}$ width, and $70 \mathrm{~cm}$ height and 2 broilers are put in one cage. Before the usage, it is better to sterilize the cage with disinfectant to prevent the broilers from bacteria and fungi. Thirty $\mathrm{cm}$ length of plastic are used to accommodate the broilers feces and cleaned every two days or three days a week.

\subsection{Broiler Chicken's}

The chicken's type that used in this research was DOC CP-707. 50 broilers that obtained from PT. Charoen Pockphand. After arriving, the broilers are given sugar water for stress relieve during the trip with ad libitum technique (Bell, 2002). Newcastle disease and Gumboro vaccine are given on days 4 and 21. Before the treatment was given, broilers will be acclimated for 14 days

\subsection{Experiment Design}

After acclimatization for seven days, broiler chickens were treated as follows. 50 broiler chickens were divided into five treatment groups. Each treatment consisted of five replications and each replication was given two chickens. The five treatments, namely control (K) were given commercial feed without suplentation of bangunbangun flour. P1, P2, P3 and P4 are groups of chickens fed supplementation 5\%,10\%, 15\% and 20\% flour. The five treatments were given for 35 days. On the 36th day all chickens were weighed and slaughtered. The liver and carcass are separated and weighed. Cholesterol analysis of meat is done with LiebermannBurchard, Cholesterol levels were measured using a spectrophotometer.

\subsection{Data Collection Technique}

\subsubsection{Body Weight Gain (BWG)}

Weight gain is obtained from the difference in the final body weight (day 36) minus the weight of the first day of treatment

\subsubsection{Percentage of Carcass}

Carcass is the meat product after the slaughter and separated from head, internal organs, fur, and legs (Tonga 2016). The percentage of carcass can be calculated by dividing the carcass weight with the life weight, the formula: Percentage of carcass is obtained by carcass weight $(\mathrm{g})$ divided by life weight $(\mathrm{g})$ multiplied by $100 \%$

\subsubsection{Liver Weight}

To obtain the liver organ, we have to slaughter the broiler first then take the liver organ from the body; put it on the tissue paper and then weighing with analytical scale. Data about the liver weight is taken on the 36th day. 


\subsubsection{Meat Cholesterol Level}

The meat cholesterol levels analyzed with Liebermann-Burchard technique (Gressner and Gressner ., 2017). A gram meat smoothed and put in to test tube. Then, drop $10 \mathrm{ml}$ of acetone and $10 \mathrm{ml}$ of $96 \%$ alcohol. Heat the test tube on the water bath until the first bubble is out and chill. After that, centrifuge the test tube with $2750 \mathrm{ppm}$ velocity for 15 minutes to get the supernatant sample and then evaporated using the oven with $40^{\circ} \mathrm{C}$ temperature. Drop $2 \mathrm{ml}$ chloroform and homogenize with shaker. Take $0.4 \mathrm{ml}$ from the fluid and transferred to another new test tube. Drop $1.6 \mathrm{ml}$ chloroform, $2 \mathrm{ml} \mathrm{H} 2 \mathrm{SO} 4$, and $2 \mathrm{ml}$ anhydrate acid and homogenize it for 5 minutes then put in to dark room. Read the absorbance using the spectrophotometer at $480 \mathrm{~nm}$ in wave. The cholesterol levels can be calculated with formula:

Sample Absorbance

$$
\begin{gathered}
\text { Cholesterol = ------------- x } 200 \text { mg/100 g } \\
\text { Standart Absorbance }
\end{gathered}
$$

\subsection{Data Analysis}

Data are expressed as Mean \pm S.E.M. and subjected to one way ANOVA followed by Post Hoc Test Using SPSS 21.0 Software.

\section{Result}

\subsection{Body Weight Gain}

The weight gain of chickens in all treatments was significantly lower than that of chicken feed for control. The lowest weight gain is in chicken treated with supplementation with $15 \%$ bangunbangun flour, while the $20 \%$ weight gain treatment is significantly higher compared to P1, P2 and P3. Chicken weight gain in all treatments can be seen in Figure.1 


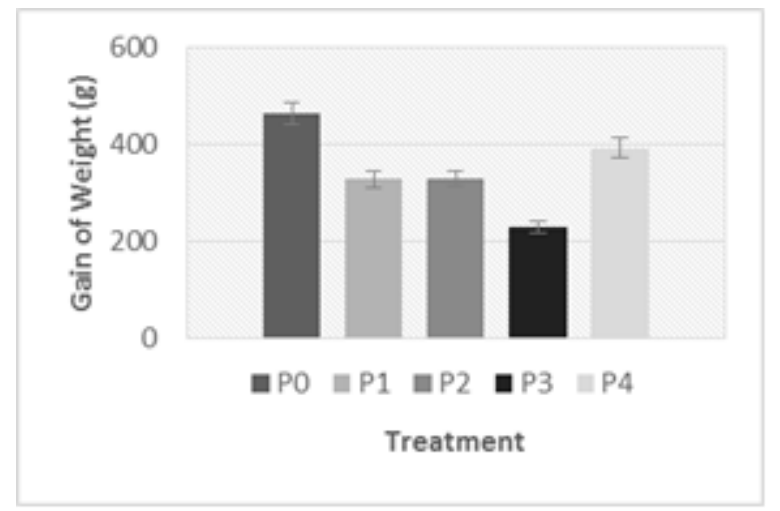

Fig. 1. The broiler Weight Gain

\subsection{Liver Weight}

The higher the percentage of supplementation of the bangunbangun flour in the feed, causing weight loss in the liver (Figure 2). Weight loss of liver organ in all treatments for meal supplementation of bangunbangun flour was significant $(\mathrm{p}<0.05)$ compared to control

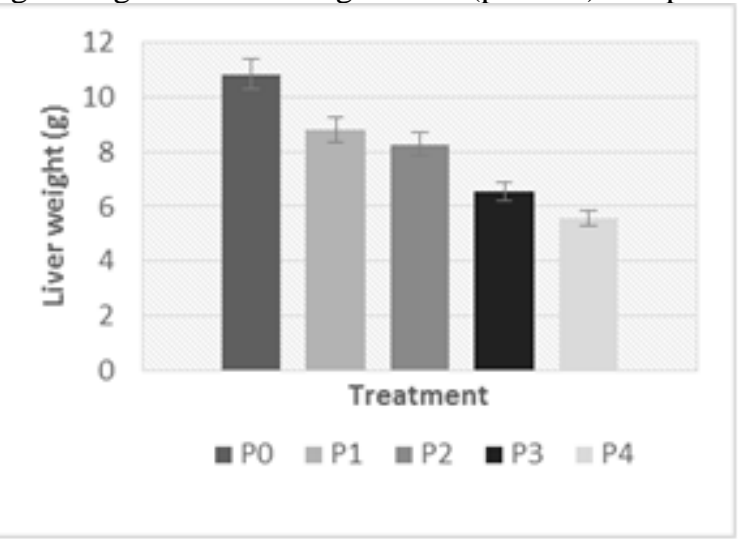

Fig 2. Liver Weight

\subsection{Carcass Weight}

Carcass weight is important in broiler farming. in this study the weight of chicken carcass fed with the supplementation of bangunbangun leaf flour decreased significantly $(p<0.05)$ if compared to the control. chickens that consumed feed supplemented with $20 \%$ of bangunbangun leaf flour did not have a significant decrease in carcass weight (Picture 3.) 


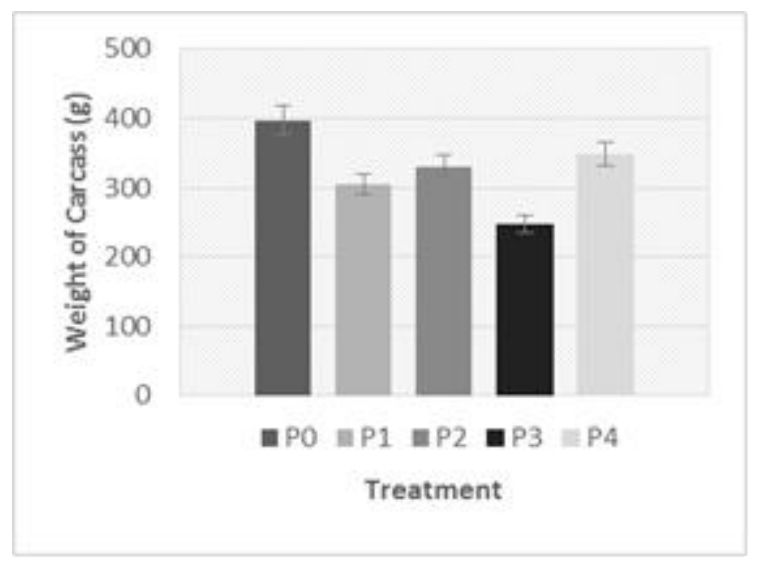

Fig 3. Weight of Carcass

\subsection{Carcass Persentage}

Although broiler chicken gain and carcass weight given feed supplementation of bangunbangun leaf flour decreased, the percentage of carcasses did not decrease. Even in P2 and P3 treatment, the percentage of carcass is higher if compared to control (Figure 4)

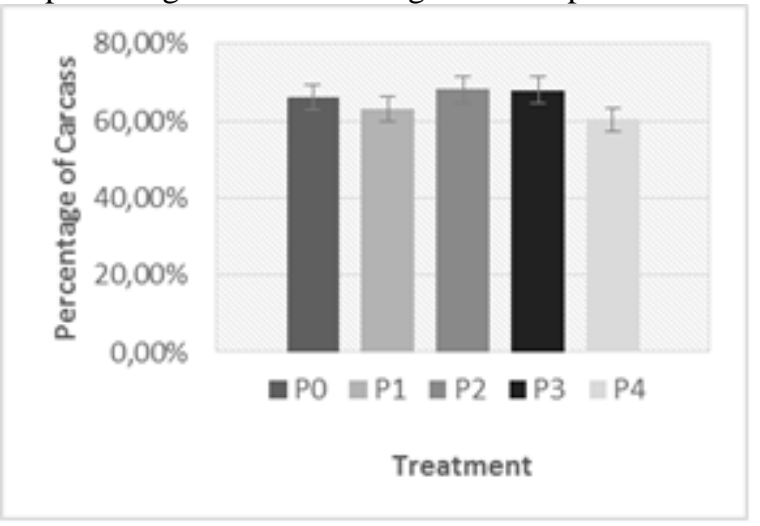

Fig 4. percentage of carcass

\subsection{Meat Cholesterol}

Feed supplementation of bangunbangun leaf flour that given to chickens can reduce meat cholesterol levels significantly. And the higher the level of leaf flour bangunbangun in the feed, the higher the decrease in cholesterol in broiler chicken meat. In this study the level of cholesterol in broiler chicken can we see in Picture 5 


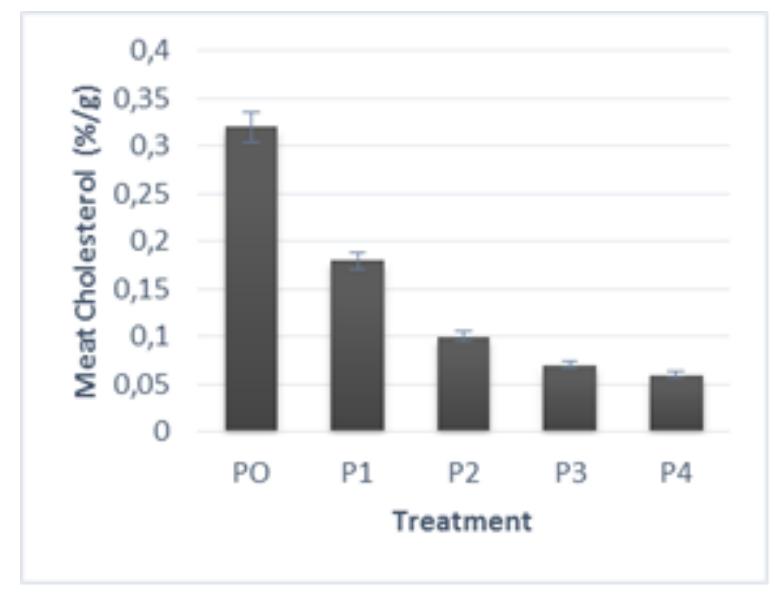

Fig 5. Cholesterol Level of Chicken Meat

\section{Discussion}

Supplementation feed with bangunbangun (Plectranthus amboincius Lour Spreng) leaves flour significantly $(\mathrm{p}<0,05)$ reduced of broilers' weight gain. This happens because bangunbangun leaves contain linalool $(50,3 \%)$ that play rule to increase the activity of microsomal hepatic enzymes which help to increase the metabolism activity (Asiimwe, 2014). According to Hullatti and Prasenjit (2011) Plectranthus amboinicus has been found to cause reduction in egg laying capacity, retard in adult emergence and weight loss in pulse beetle Callosobruches naculatus. Bangunbangun leaves did not influence the increasing of rats body weight Silitonga et al (2014). Moreover, bangunbangun also contain Niacin that affects the regulation of fat acid in the body. Niacin is proven increases the free fat acid that affect the activity of beta-pancreas cell to produce insulin. As we know that insulin is play an important rule to regulating blood glucose level and human metabolism.

Liver is an organ that plays an important rule on cholesterol formation and storage. In its formation, carbohydrates obtained from food and processed by body storage in 3 forms, there are cholesterol, glycogen, and fat. Not only synthesized, liver also catabolised fat acid.

Liver also regulate the cholesterol synthesis, esterefication, and excretion. The serum of cholesterol is one of cholesterol tes standart needed. Based on explanation above, liver weight is use to be one of parameter to know the level of cholesterol in an organ that absolutely also affect a whole body.

In this study feed that supplemented with $20 \%$ of bangunbangun flour reduced of liver weight. Bangunbangun leaves, contain carvacrol and niacin that potential to prevent the hypercolesterol symptom in liver. This statement also supported by Santi et al (2015) research, that niacin have the potential affect to inhibit the tissue fat changes, decrease the taking of free fat acid by intestine from the food and also increase the cholesterol removal by the bile.

One-Way ANAVA test showed that, the higher dose given, then the liver weight also lower. This happened because, there is a decreasing of cholesterol synthesize in liver. This statement supported that supplemetation feed by bangunbangun leaves flour can inhibit the 
cholesterol formation in liver. So that, the other tissue that also potential contain cholesterol such as meat also decreasing.

From the occurrence of liver weight while the higher doses given, give a conclusion that the supplementation of bangunbangun leaves flour decrease the cholesterol level in the body. This is because bangunbangun contains niacin or nicotinate acid that affect the cholesterol flushing in blood vessel (Koti et al., 2011 and Haryanto et al., 2017). Niasin is a vitamin Bkompleks derivate such as coenzim NAD (nicotin amide-adenin dinukleotida) and NADP (nicotin amide-adenin dinukleotida fosfat) which are have a very important role in oxidatingreduction process. The decreasing of plasma cholesterol level happen because the niacin inhibit the activity of hydoxy-metilflutaril KoA (HMG-KoA reduktase) in liver, so that the change process of mevalonat acid also inhibited and at last forming the squalent, and the level of cholesterol also decreasing (Peter and Bothamr, 2003).

Final carcass weight and carcass percentage are the most concern of. Because broilers as well known as chicken meat product. In big farm, this parameters also affect the production. The carcass percentage calculated with formula. In this study showed that the supplementation feed with bangunbangun leaves flour doesn't significantly $(p>0.05)$ increased weight and percentage of carcass. As the explanation before, that bangunbangun contains niacin, linalool, and carvavrol that affect the broilers' metabolism and decrease the body weight that also affect the weight and percentage of carcass (Asiimwee, 2014).

Cholesterol is the result of fat acid breakdown in liver and storage in liver and another tissue such as meat in broiler. According to Strain (n.d) and Wattanachant et al (2004), the normal level of meat cholesterol in broiler is $284,92 \mathrm{mg} \% / 100 \mathrm{~g}$ samples or $2,84 \mathrm{mg} \% / 1 \mathrm{~g}$ samples. In this research, the higest dose is $20 \% / 100 \mathrm{~g}$ commercial feed showed that the meat cholesterol level value is $0.069 \mathrm{mg} \% / 1 \mathrm{~g}$ sample or a 2,42\% lower compared with the normal level.

The percentage of carcasses did not decrease even though the weight and weight of the carcass decreased with the feeding supplemented with bangunbangun flour. Decreased body weight in line with decreased cholesterol levels in the meat. Decreasing cholesterol levels in the meat is a desired thing in accordance with the background of the problems described earlier.

The decreasing of meat cholesterol levels also in line with the decreasing of liver weight. Decrease in cholesterol levels in chicken meat is in line with the results of research by Sihite and Silitonga (2018). More lower of liver weight, the cholesterol level in body also getting lower. Recall that bangunbangun contain niacin and linalool that have an important role in cholesterol flushing in blood vesels. Linalool also can activated the metabolism enzyme in the body.

\section{Conclusion}

1. Feed supplementation of bangunbangun leaf flour reduces the weight of broiler chickens

2. Feed supplementation of bangunbangun leaf flour decreased of carcass weight but does not affect the percentage of carcass

3. Feed supplementation of bangunbangun leaf flour decreased liver weight, and cholesterol in broiler chicken meat 
Acknowledgments. Our thanks go to the State University of Medan's biology and biochemistry laboratories for their permission in conducting data research and analysis

\section{References}

[1] Asiimwe.S, Karlsson, A.B, Azeem, M . Kamatenesi-Mugisha, M, Namutebi, A dan N.J. Gakunga.. Chemical composition and Toxicological evaluation of the aqueous leaf extracts of Plectranthus amboinicus Lour. Spreng. Intern. Journal of Pharmaceutical Science Invention.3: 19 - 27.( 2014)

[2] Bell, D. D.. A Model Integrated Broiler Firm. Commercial Chicken Meat and Egg Production, 819-827. doi:10.1007/978-1-4615-0811-3_42. (2002)

[3] Gressner, A. M., \& Gressner, O. A.. Liebermann-Burchard-Reaktion. Lexikon Der Medizinischen Laboratoriums diagnostik, 1-1. doi:10.1007/978-3-662-49054-9_3695-1. (2017)

[4] Peter A. M. \& K.M. Botham,. Cholesterol Synthesis, Transport, \& Excretion. Harper's Illustrated Biochemistry. 26 edition Lange Medical Books/McGraw-Hill p:219-230. (2003)

[5] Haryanto, A., Purwaningr, M., Andityas, M., \& Wijayanti, N.. Effect of Chicken Feather Meal on the Feed Conversion Ratio and Blood Lipid Profile of Broiler Chickens. Asian Journal of Poultry Science, 11(2), 64-69. doi:10.3923/ajpsaj.2017.64.69. (2017)

[6] Hullatti, K., \& Bhattacharjee, P. Pharmacognostical Evaluation of Different Parts of Coleus amboinicus lour., Lamiaceae. Pharmacognosy Journal, 3(24), 39-44. doi:10.5530/pj.2011.24.8. (2011).

[7] Koti, B., Thippeswamy, A. H. M., Viswanathaswamy, A. H. M., Gore, A., \& Kulkarni, R. Antihyperglycemic and antihyperlipidemic activity of Plectranthus amboinicus on normal and alloxan-induced diabetic rats. Indian Journal of Pharmaceutical Sciences, 73(2), 139. doi:10.4103/0250-474x.91572. (2011).

[8] Kumar, S., Singh, S. K., Singh, R., \& Singh, A. K.. Animal Biometrics. doi:10.1007/978-981-10-7956-6. (2017)

[9] Marangoni, F., Corsello, G., Cricelli, C., Ferrara, N., Ghiselli, A., Lucchin, L., \& Poli, A. Role of poultry meat in a balanced diet aimed at maintaining health and wellbeing: an Italian consensus document. Food \& Nutrition Research, 59(1), 27606. doi:10.3402/fnr.v59.27606. (2015).

[10] Muthukumarana, R., \& Dharmadasa, R. M. Pharmacognostical investigation of Plectranthus hadiensis (Forssk.) Schweinf. ex Sprenger. and Plectranthus amboinicus (Lour.) Spreng. World Journal of Agricultural Research, 2(5), 240-246. doi:10.12691/wjar2-5-7. (2014).

[11] Santi, M. A., Sumiati, S., \& Abdullah, L. Cholesterol and Malondialdehyde Contents of Broiler-Chicken Meat Supplemented with Indigofera zolingeriana Top Leaf Meal. Media Peternakan, 38(3), 163-168. doi:10.5398/medpet.2015.38.3.163. (2015).

[12] Sihite, A. C., \& Silitonga, M. Berat badan dan kadar kolesterol organ-organ dalam ayam broiler yang diberi pakan suplementasi tepung daun bangunbangun (Plectranthus amboinicus L. Spreng). Jurnal Biosains, 4(1), 55. doi:10.24114/jbio.v4i1.9789. (2018).

[13] Silitonga, M., Ilyas, S., Hutahaean, S., \& Sipahutar, H. Levels of Apigenin and Immunostimulatory Activity of Leaf Extracts of Bangunbangun (Plectranthus Amboinicus Lour). International Journal of Biology, 7(1). doi:10.5539/ijb.v7n1p46. (2014).

[14] Strain, J. H. (n.d.). Genetic-economic factors in broiler meat production. doi: $10.31274 /$ rtd-180813-460 
[15] Wattanachant, S., Benjakul, S., \& Ledward, D. A. Composition, Color, and Texture of Thai Indigenous and Broiler Chicken Muscles. Poultry Science, 83(1), 123-128. doi:10.1093/ps/83.1.123. (2004). 